\title{
Endangering the Endangered: Impact of fake Covid-19 Social Media Communications in Zimbabwe
}

\author{
Isaac Mhute, Hugh Mangeya, Ernest Jakaza \\ Department of English and Communication \\ Midlands State University \\ PO Box 100, Zvishavane, Zimbabwe \\ E-mail:mhutei@staff.msu.ac.zw
}

\begin{abstract}
The human species is in great danger of extinction due to the novel coronavirus that was first detected in China around December 2019. By March 2021, the world had witnessed over 116 million cases, of which 36,223 are Zimbabwean. The disease that the coronavirus stimulates is quite fatal and has seen 2.57million lives succumbing to it, of which 1483 are Zimbabwean, by the same date. No cure has been discovered for it yet, though scientific researchers have already discovered several vaccines with varying efficacies. Employing a socio-pragmatic approach, the chapter explores the impact of fake covid-19 social media communications on efforts to minimize infections and fatalities in Zimbabwe, an already endangered country. It accomplishes this by qualitatively analyzing purposively sampled fake communications in circulation on social media as well as some of the utterances and behaviors people make in response to them. The chapter demonstrates the negative impact of the communications on international mitigating efforts and emphasizes the need for the government, media practitioners and social workers to always be watchful for such misleading communications and in every case to quickly counter their impact by availing correct information to the people.
\end{abstract}

Keywords: Coronavirus, Covid-19, fake social media communications, socio-pragmatics.

\section{Introduction}

People do not live in isolation but rather consider themselves bona-fide members of a common social community. This is the globalized world Thompson (1995) describes as the growing interconnection of different parts of the world that gives rise to complex forms of interaction and interdependency. With the emerging advanced communication networks, the entire world has been effectively compressed into a village. This is reiterated by Albrow (1990) who notes that through globalization, all the peoples of the world are incorporated into a single world society.Everyone in this society often find themselves being informed and advised on issues pertinent to their well-being through various platforms. As such, they also feel obliged to share their experiences, opinions, worries and joys for the benefit of the society.

To enhance the interaction, most of them have since affiliated to various communication platforms on social media, such as WhatsApp, Facebook and twitter. The impact of such platforms is heightened by the fact that, by their nature, humans often live a life of influencing each other, either knowingly or unknowingly, into behaving in different ways. As such, communications from various sectors of the society have often shaped the way people perceive reality and behave in different environments. To validate this claim, Burke et al. (2009) arguethat various studies have demonstrated how social media bears a lion's share in influencing people, especially the youth, into behaving the way they do. Unfortunately, as Khan and Idris (2019) note, some tend to trust online sources of information such that they find it unnecessary to verify them either due to ignorance or lacking the verification skills. 
The current study belongs to the context of Covid-19, a novel disease that has been declared a world pandemic by $\mathrm{WHO}(\mathrm{WHO}, 2020)$ and for which the necessary information pertaining to its behavior, vaccination and cure have not been adequately uncovered yet. The research was undertaken during a period characterized by many questions relating to the origin and nature of the corona virus, its link to some historical and biblical narratives people have as well as effects of the vaccines. The period also saw varied efforts by different sections of the world to fill the void by availing the much-needed answers through explanations, some biblical, some scientific and others pseudo-scientific (WHO, 2020). Such answers and explanations are appealing to the entire world in different ways thereby tempting people to react in various ways some of which quite futile to their welfare. Frenkel et al. (2020) confirm this by noting that Africa is besieged with so many misconceptions and/or misinformation about Covid-19 via the media, social commentators and social media. The current study set to trigger the harnessing of such misconceptions in Zimbabwe, a developing nation already vulnerable to the pandemic due to limited medical resources and imminent economic meltdown. Their difficult situation was captured by Muronzi's (2020) report that Zimbabweans indicate they are more worried of hunger than Covid-19, an approach placing their lives at high risk.

Due to the rampant economic difficulties, most Zimbabweans are poised to accept fake social media communications as they have limited access to historical backgrounds of their originators' evil intentions because of limited and/or unaffordable internet access. Such vulnerable communities are perceived by the study as endangered already (Bill Gates, https://www.edition.cnn.com). This was also reiterated by the WHO experts who confessed their huge concern for vulnerable continents, especially Africa, as they are not prepared to contain a pandemic of this magnitude (www.sokodirectory.com). They observed that the level of preparedness in Africa was pathetic with no emergency funds and generally poor health facilities. For instance, there are only five intensive care beds for every one million people in Africa compared to four hundred thousand for everyone million people in Europe (WHO, 2020). They also indicate that, whilst the fight against the coronavirus emphasizes on hygiene and maintenance of social distance, sixty percent of Africa (Zimbabwe included) are low income earners struggling to spare anything for face masks and recommended sanitizers with sixty percent alcohol content as they are already unable to afford daily basics (WHO, 2020).

Zimbabwe's ill-equipped fight against the pandemic was worsened by shortage of test resources. Mabunda (2020) reports that as of 10 April 2020, Zimbabwe had only tested 400 people at a time Rwanda had tested over 1,500 people in two days and South Africa had had a total of over 70000 . Furthermore, as of July 2020, people were continuously demonstrating in and fleeing from quarantine centers alleging the delays in testing to be exposing them to unnecessary risks of contracting the virus (https://www.zimeye.net). By February 2021, Zimbabwe had only secured 600thousand Sinopharm doses donated by China for her population estimated to be 15 million (World Bank, 2019) at a time other countries in and outside Africa had already vaccinated millions of their citizens. This demonstrates how vulnerable the community in question is to Covid-19 and the reason for the need to assess how it is being endangered further by the fake social media communications on the pandemic.

Fake social media communications are hereby defined as social media claims that are false or unverified due to lack of scientific evidence (Chou et al., 2018). Kwak et al. (2010) refer to fake social media as the large percentage of retweets which spread very quickly during crisis events and that, as they circulate, they lose touch with their origins, including the period and circumstances surrounding the original post, making it difficult for the responders to verify them.

Brennen et al. (2020) conclude that misinformation about science, technology and health is not new to the study of crisis communication and neither is it unique to Covid-19. For instance, during the Zika virus pandemic, misleading posts related to the Zika virus were rampant on social media, being more popular than authentic public health posts about the pandemic (Sharma et al. 2016). Chadwick \& Vaccari (2019) echo Sharma et al. (2016) noting that 
considerably huge volumes of social media misinformation are sometimes shared more frequently than authentic news.

\section{Theoretical Framework}

This study was inspired by several components of pragmatics as an approach to encoding and decoding of meaning and their possible effects during communications. Pragmatics is a sub-field of linguistics and semiotics that studies the ways in which context contributes to meaning. Unlike semantics, which examines conventional meaning, pragmatics studies, among other things, how the transmission of meaning depends not only on structural and linguistic knowledge (such as grammar and lexical aspects) of the speaker and listener but also on the context of the utterance, any existing knowledge related to those involved and the inferred intent of the speaker. Focus of this study was on the socio-pragmatics dimension of pragmatics which perceives usage and interpretation as primarily determined by social factors in communication (Hickey, 2015). There was interest in exploring how the fake social media communications on the novel coronavirus and the subsequent disease were likely to be interpreted by the vulnerable Zimbabwean populace in the light of their environment and experiences as well as the possible reactions to them and their possible consequences.

Speech act theory, a major component of the approach in question, asserts that every statement has two things attached to it, that is, saying something and doing something. Austin classified the second dimension as the performative feature arguing that through it, statements become instrumental in achieving an interactional goal between two or more speakers (Schiffrin, Tannen and Hamilton, 2003). One can consider the conspiracy in circulation on WhatsApp that 'Coronavirus does not infect everyone as it is a deliberate biological weapon specifically meant for China's enemies', which performs the act of declaring an assurance that non-Chinese enemies are safe. With the statement's performance, the recipients are bound to react say by developing a feeling of safety and according themselves freedom from the imposed precautionary measures. It then emerges as a possible force behind the many cases the police have always considered as defiance of the lockdown regulations. Such performative features of fake social media communications were analyzed to establish their dangerousness and possible contribution to the soaring in the confirmed corona virus cases and death toll in Zimbabwe.

Felicity conditions, as stated by the speech act theory, are also key to the study. According to them, success of every speech act is dependent on several extra-linguistic conditions. For instance, for the performative feature in the illustration above to be complete, the speaker must either be a medical practitioner or one with considerable links that properly position $\mathrm{him} /$ her for making such claims. Once that condition is in place then the performative utterance becomes felicitous. The study explores how the nature of the felicity conditions surrounding the performative features of the fake Covid-19 social media communications are tempting the Zimbabwean recipients to believe in their claims as well as behaving accordingly and consequently succumbing to the intended damage.

The English philosopher Paul Grice (1913-1988), in his contribution to pragmatics, got concerned with the task of accounting for how human beings behave in normal conversations. To this end, he introduced the notion of conversational implicatures which are implications deduced by speakers during conversations (Searle, 1969). For him, people do not only take the meaning coded in the statements they are confronted with but rather, they tend to go beyond them and draw implications based on their current situations as well as their experiences. For instance, for the example presented earlier, Zimbabweans are aware of their good economic and political relations with China and would proceed to deduce that the virus has nothing to do with them.

\section{Covid-19, a Biological Weapon Solely Infecting China's Enemies}


The outbreak of corona virus was followed by a voice note, which started circulating as early as end of January or beginning of February 2020, alleging that the story of corona virus as having originated from wild animals and transmitted into humans is rather a cover-up effort by the Chinese government. The man with a native American English accent featuring in the voice note claims to be an American national and alleges that the virus is rather one of the many artificial weapons crafted by the Chinese for their biological warfare against their enemies such as the USA and some countries in Europe. The voice note claims the virus would be specifically spread to and infect these enemies only. It alleges as well that the pictures of dead Chinese in circulation are old and not from the current pandemic.

The claim attained support from various articles like one published in the Magzter magazine on the $11^{\text {th }}$ of May 2020 entitled 'Outraged Experts Charge: Coronavirus is Chinese Bioweapon!' alleging that coronavirus was deliberately engineered as a bioweapon in a Chinese laboratory (https://www.magzter.com). In addition, several aspects validate the claim such as the perennial enmity between Chinese and Americans as competing superpowers. Also, immediately after the outbreak of coronavirus, the USA, through their Secretary of State, Mike Pompeo, was so quick to dismiss Chinese explanations in a television interview and went on to allege that they had kept silent for too long and handled the virus negligently thereby endangering the whole world due to some hidden agenda (http://www.time.com). In light of such a background, a voice note alleging the Chinese to be culprits solely targeting the United States of America and several others become too tempting to resist.

Secondly, featuring of a man with a native American English accent in the voice note made his claim of being an American citizen believable. The American citizenship serves as a proper background for the acceptability of the claim as it properly positions him for accessing even some very sensitive information relating to the two superpowers. He also specified that he had a close link to some boss in the Chinese army who was intentionally leaking the confidential information just to alert their nation's enemies about the planned damage on humanitarian grounds. Such efforts to attach the information to a source with obvious access to such sensitive information clears any possible doubt thereby adding weight to the claim. The humanitarian reason raised is quite convincing in such crisis situations as well.

The timing for sharing the voice note was also perfect. By the time it subsequently conquered most social media platforms, the USA and some countries in Europe, considered China's biggest enemies, were leading the entire world in both confirmed positive cases and fatalities. At the time, most African countries, like Zimbabwe, were yet to record even a single case making the conspiracy an appealing explanation for the situation.

As a result, some Zimbabweans could be heard in anecdotal interactive situations defending their roaming around in defiance of the lockdown saying 'corona hainei nesu, ine varidzi vayo' (the coronavirus has nothing to do with us, it has its specific targets). Thus some Zimbabweans had dangerously gained enough confidence to excuse themselves from the prospective victims due to the well-known good relations with China. This confirms Ahinkorah et al.'s (2020) observation that the dissemination of misinformation can powerfully impact people's actions and reverse the value of the interventions employed by local governments through their health institutions and other stakeholders. Such impact of the claims needs to be combated with the seriousness it deserves. Fortunately, for this claim, though the USA and some European countries kept making statements maintaining the bioweapon conspiracy, other efforts were being made by properly positioned personnel to reverse it. For instance, on the $14^{\text {th }}$ of July 2020, a Ukraine scientist, Professor Sergiy Komisarenko, featured on http://www.newseu.cgtn.com pouring scorn on the idea that Covid-19 could be an artificially constructed bioweapon from a Chinese laboratory.

\section{Covid-19: God's Punishment for Same-Sex Marriage}

In May 2020, a text went viral on social media platforms like WhatsApp and Facebook labeling Covid-19 as nothing other than God's punishment against same-sex marriages. It described 
Covid-19 as not a disease but a rebuke against this specific sin and for which only repentance was the cure. The message was supported by its coverage on various websites like the mint e-paper (www.livemint.com) which presented it as 'God's divine punishment'. It also got a major boost from its link to prominent church leaders like the Ukrainian Orthodox Church head, Patriarch Filaret, who CNN's Harmeet Kaur had to later report about on the $9^{\text {th }}$ of September 2020 saying, 'A prominent Ukrainian church leader who previously said Covid-19 pandemic was 'God's Punishment' for same-sex marriage has tested positive for Covid-19'. The timing for the message made it more appealing as mid-2019, just before the beginning of Covid-19, was characterized by considerable resolutions to allow same-sex marriages. For instance, on the $21^{\text {st }}$ of June 2019, MPRnews' Nina Moini published a story entitled 'Minnesota Methodists resolve to allow officiating of same-sex unions LGBT ordination' a move in response to the denomination's global conference to maintain rules against officiating at same-sex unions and gay ordination.

To some Christian Zimbabweans, this was sensible as the disease initially appeared to be descending heavily on nations who had shown signs of legalizing the sinful actions. To demonstrate the message's impact, some could be heard at the time quoting biblical verses to support the call for repentance like Lamentations 3:40 saying 'Let us search and examine our ways and return to God'. Others could also be heard citing Proverbs 3:12 saying 'For whom God loves, God rebukes' arguing that it has been like that even with the Israelites whom, despite being the Almighty's favorites, Assyrians, for instance, were often set against them to rebuke their evil deeds. For believers, such scriptural evidence properly boosted the message's appeal thereby according some Zimbabweans who had not committed the sin an urge to relax, and even defy precautionary measures against the pandemic.

\section{Covid-19 as Radio-Frequency Radiation from 5G Network}

A voice note flooded WhatsApp groups around March 2020 featuring a Zimbabwean citizen claiming to be living in Italy who decided to take advantage of his access to information and inform his fellow Zimbabweans about the 'truth behind the pandemic'. He confirms that people are really dying as evident on the media. However, he alleges that there is nothing like coronavirus adding that the illness claiming thousands of lives is rather a result of the fifthgeneration cellular network being launched by developed countries. After providing some considerable background to the $5 \mathrm{G}$ network, the man, often codeswitching between English and Shona, argues that 'munhu wose ane magetsi mumuviri' (every human body has some radio frequency) and as such, there is a reaction of human bodies to the $5 \mathrm{G}$ radio-frequency radiation which is the reason it affects the Chinese, Americans, Italians, Spanish and other developed countries who have already commenced launching of $5 \mathrm{G}$ network.

Support for the conspiracy came from the featuring of a man comfortably codeswitching between English and Shona (a majority Zimbabwean language). His Zimbabwean background aided his seemingly genuine concern for fellow countrymen. His claim that he was working in Italy (supported by good understanding of $5 \mathrm{G}$ network), one of the first countries to suffer the most after China, made him properly positioned for having the alleged access to information. The claim also coincided with the fact that Huawan, considered to be the epicenter of the corona virus, is one of the very first places where the $5 \mathrm{G}$ network was launched.

Again, the timing was proper as only the developed countries appeared vulnerable to the illness at the time the voice note fully conquered the social media. In addition, at the time in question, South Africa who seemed to be the only African country in the region that was showing clear indications of being threatened by Covid-19 was claimed to have started launching the 5G network. Her Gauteng province, considered South African Covid-19 epicenter, is also the one that was alleged to have $5 \mathrm{G}$ boosters erected at the time. This made the claim considerably tempting to resist and many Zimbabweans in South Africa could be heard advising colleagues back home that 'corona iri kuno, ikoko hakuna' (coronavirus is here not over there). Many were returning home as reported by Maromo (2020) in an article entitled 
'Hundreds of Zimbabweans Leave South Africa in Assisted Repatriation'. Obviously, a considerable number believed Zimbabwe to be safe and appropriate for living normally thereby fueling defying of lockdown restrictions.

France 24 (http://www.twitter.com) confirmed the man behind this conspiracy to be a Zimbabwean. The Guardian on 27 April 2020 went a step further revealing his name as James (https://www.theguardian.com). In the note, James could also be heard saying due to his position as a Vodafone executive, 'God blessed me with the ability to bring desperate pieces of information together that makes sense out of the puzzle.' He alleged in the recording that Bill Gates is involved in a plot to produce corona virus microchips to track individuals, a move that would ultimately herald the destruction of society. He claims to be warning the public that the pandemic is a cover for a global plot to install 5G mobile phone masts, track the world's population through vaccines and then destroy the entire human society. The detailed background and the appropriate jargon appealed properly to ordinary people and is also aided by his acknowledgement of God's blessing that accorded him the opportunity to inform the scared countrymen. Reference to the installation of corona virus microchips also appeared too convincing to Christians as they could easily connect it to the Biblical fulfillment of the much-awaited end-time prophecy of the triple 6 mark of the devil in Revelations. Linking it to Bill Gates revived the Christians' belief in the possibility of an imminent fulfillment of this prophecy that was triggered when former USA president, Barack Obama, alluded to a suggestion for having some microchips inserted into Americans for easy access to health care facilities. In light of this, one can safely argue that the claim contributes to many Zimbabweans' resistance to vaccination.

The claim's other boost was that initially Zimbabwean cases were of returnees who had resided in or recently traveled to developed countries with the $5 \mathrm{G}$ network. This cemented the belief so much that as of March 2021, people reaching medical institutions would first be questioned about their travel history. Another boost for the claim came inform of destruction of the $5 \mathrm{G}$ boosters in a number of places including Wuhan during the period the communication conquered the media. This sent an impression that the answer to the illness had been found and had nothing to do with them. It is the reason as of July 2020, some Zimbabweans could be heard saying corona 'chirwere chevapfumi kwete isu varombo' (coronavirus is a disease for the rich, not us the poor). Thus, they still considered it not a threat at all to their poor country demonstrating how such fake news can influence people's behavior. This got confirmed when The Guardian contacted James who got shocked that a private message intended for a small group went viral and was covered on various social media platforms. Hill (2012) reiterates by observing that both purposeful and accidental misinformation have often diffused through social media and sometimes into the established media platforms.

Fortunately, for this specific claim, Tawanda Chikosi also published an article on the $22^{\text {nd }}$ of April 2020 entitled 'Zimbabwe: Potraz Demystifies Link between Covid-19 and 5G Network' reporting that Potraz General Director, Dr Gift Machengete dismissed the possibility of any scientific link between the fifth-generation cellular network and Covid-19 (https://www.allafrica.net). This demonstrates that explosion of misinformation, disinformation, fake news and conspiracy theories around coronavirus has become a pressing concern for global health care authorities which justifies WHO's warning that the world is facing not only Covid-19 pandemic but also a related infodemic (Hua \& Shaw, 2020).

\section{China as Intentionally Trying to Infect Zimbabweans}

While some communications alluded to earlier suggest China as targeting her enemies, there are social media communications alleging her of intending to infect and wipe away Zimbabweans as well. Prophet Emmanuel Makandiwa, who foretold the coming of the novel virus, features in a social media video in April 2020 alleging 'there is nothing wrong with us. Rather, the developed countries are eager to inject us with the virus.' He claims the 
government would soon be allowing compulsory testing and injection and promises if they do so, 'I and my family are going to jail for defying government instructions'. He advises people not to fall for it as 'it is the developed countries' plan to infect us and then test their vaccines on us and kill us'. The claim was also captured by The Standard in an article entitled 'Makandiwa, Bill Gates Vaccines and Microchips' indicating that whilst viral social media posts claim that Bill Gates plans to test new corona virus vaccines on Africans, in a Sunday 5 April 2020 sermon, Preacher Makandiwa also claimed that there is a plan to inject electronic implants into people under the guise of Covid-19 vaccinations. The message was so appealing for many Zimbabweans to avoid being tested for Covid-19 firstly, because HIV is another virus alleged to have been created by developed countries for destroying blacks and whose vaccines are continuously being tested in countries including Zimbabwe. Secondly, the prophet is a model for many in Zimbabwe who foretold the coming of the virus way before its outbreak and was sending a warning message to people who were shocked by the rate at which the virus was destroying the developed nations. Thirdly, the video hit social media when his second corona virus-related prophecy had just materialized through the foretold Chinese doctors' visit with donations for combating Covid-19 and whose departure was followed by a sudden increase in corona virus cases in Zimbabwe.

The number of confirmed cases rose by more than one hundred percent in a day just after the doctors' departure and people started speculating about the danger associated with the test kits and masks brought by the Chinese doctors as alleged in the prophecy. For many Zimbabweans, it meant corona virus was being intentionally brought into the country by Chinese. The claim got boosted by several European countries' turning back of alleged Chinese faulty face masks in April. This was also captured by an article published by the Indian Express on 10 April 2020 that listed Spain, Netherlands, Turkey and Australia as having returned Chinese-bought face masks as faulty. People started talking about the danger associated with Chinese test kits and face masks. As of July 2020 many Zimbabweans expressed fear of testing and some were even putting their lives in danger by hiding returning relatives in homes when the law said should first proceed to appropriate centers for quarantining and testing. This could be the explanation behind the returnees' running away from quarantine centers before they were tested thereby endangering the entire nation.

One Zimbabwean man said, 'Handipfeki mask ini, hamuna corona muno. Kana ndamanikidzwa nemapurisa, ndingatosona yangu pane kutenga nokuti mukana wekutenga yekuChina ine corona nechekare wakakura.' (I do not wear a face mask, there is no corona here. If forced by the police, I would rather make my own face mask rather than buying because the chances of buying an already infected one from China are very high.) Thus, courtesy of the fake claims, all Chinese Covid-19 humanitarian efforts to save Zimbabweans were perceived as linked to some evil intentions to spread the coronavirus due to the fake social media communications. It also explains some Zimbabweans' resistance to the Chinese Sinopharm vaccine. This confirms Kim, Fast, and Markuzon's (2020) assertion that misinformation influences public responses to pandemics thereby altering effectiveness of national countermeasures.It also explains Hughes et al.'s (2014) observation that misinformation is one major reason many emergency responders refuse to assimilate social media into their emergency response routines.

\section{Coronavirus as vulnerable to hot water with lemon}

A voice note started circulating around March 2020 featuring a Zimbabwean claiming to have been advised by an Israelite church mate that there was an easy remedy to cure COVID-19. He advised fellow Zimbabweans not to panic as the novel virus could easily be killed by drinking hot water with lemon. The claim went so viral that Davis (2020) had to publish a counter article in April 2020 entitled 'Debunked: No, Lemon in Hot Water is not a Cure for Covid-19', reporting that WHO experts were worried that a wave of disinformation had developed during such a difficult time. The claim got boosted by the coronavirus' nature as a respiratory disease like influenza typically combated by Zimbabweans using lemon. The 
impact of the communication on Zimbabweans could be seen in some asking for lemons from neighbors saying 'toda kumborapa corona' (we want to cure corona). It could also be seen in increased sale of lemons in streets and the marked rise in their price from around April. Another text message linked to the voice note read:

\author{
Functions of Lemon: -boosting vitamin C \\ -treatment of Covid-19 \\ -treatment of influenza.
}

To demonstrate the impact of such messages further, people could be heard talking to each other saying 'haufaniri kunetseka nezveCovid, ingojairira kunwa mvura ine lemon ichidziya kamwe chete mumazuva maviri oga oga, hauna chaunoona' (you just don't have to worry much about Covid, just make a habit of drinking hot lemon water once in every 2 days and you are safe). This confirms Frenkel et al.'s (2020) argument that Africa is besieged with so many misconceptions and/or misinformation about Covid-19 via the media, social commentators as well as the social media. Pennycook et al. (2020a) reiterated this by noting that people are being misled by various conspiracy theories ranging from Covid-19 as a biological weapon to break the economic power of China against other economically endowed nations like the USA to the use of local herbs to cure the virus. Such false beliefs from fake communications could be the reason many Zimbabweans were arrested for taking the novel virus lightly by roaming around without face masks in locations, dropping face masks in towns and defying the calls to stay indoors and maintain social distance which resulted in the trend of increased local transmissions in the country.

\title{
Covid-19 as killing the elderly on chronic illness medication
}

When the cases were on the rise in the USA and Europe killing hundreds in a single day, texts and voice notes circulated on social media advising people not to panic as the disease only threatened old people suffering from diabetes, hypertension and other chronic illnesses keeping them on treatment. They alleged the virus finds the immune system of such people already compromised and unable to withstand the pressure from the virus. They claimed if one is not elderly and not on such medications, the virus' effect would not be so pronounced and vanish like influenza. The claim went so viral that on the $22^{\text {nd }}$ of March 2020, Dr Louise Aronson of the University of California had to respond with an article entitled 'Covid-19 Kills only Old People on Medication. Only?' vehemently refuting the idea.

The boost for the fake claim came from the fact that as of July 2020, Covid-19 had mainly wreaked havoc in developed countries like the UK, Italy, Spain and the USA who coincidentally have many such elderly people due to their high life expectancy. Such messages boosted Zimbabweans' confidence and basically the reason many do not put on face masks or maintain social distance unless when members of the police force are in sight (The Financial Gazette, 2020). This also prompted a comment by Aljazeera Live News Zimbabwe (2020) that there is rather more fear of hunger and the police force than there is for the novel corona virus whose global confirmed cases have surpassed 10 million as of the $28^{\text {th }}$ of June 2020 with 500 thousand deaths. This confirms the observation that misinformation about coronavirus was noticed proliferating on social media threatening to make the COVID-19 pandemic worse (Policy Briefing, 2020). Hu et al. (2020) reiterated this by noting that in many instances, misinformation has weakened and interrupted global efforts to fight epidemics.

\section{Conclusion}

The chapter has demonstrated how the strength of fake social media Covid-19-related communications are in misleading Zimbabweans, a developing country that is already in danger due to limited medical facilities necessary for combating a pandemic of such magnitude. The danger is quite pronounced because currently the WHO is banking solely on positive behaviour-change and vaccination in the fight against coronavirus. Due to the fake 
news inspired beliefs, most of the people have become quite adamant and no longer think twice before they defy safety measures such as maintaining hygiene and social distancing rules, walking with no masks and resisting vaccinations. The study advocates for the government and other concerned organizations to not only call for the arrest of those who defy regulations, but also combat the cause of it through keeping an eye on the various social media platforms so as to quickly uproot every one of them by availing the necessary information as people are basically tempted to fall for them because of lack of information.

\section{References}

Ahinkorah, B.O. (2020). Rising Above Misinformation or Fake News in Africa: Another Strategy to Control Covid-19 Spread. Available online at https://www.doi.org Accessed 11/07/2020.

Aljazeera Live News Zimbabwe (2020). 'We'll Die of Hunger First': Despair as Zimbabwe Lockdown Begins. Available online at https://www.aljazeera.com Accessed 12/07/2020.

Aronson, L. (2020). Covid-19 Kills Only Old People on Medication. Only? Available online at https://www.nytimes.com Accessed 12/07/20.

Brennen, S., Simon, F.M. \& Nielsen, R.K.(2020) Beyond (Mis) Representation: Visuals in COVID-19 Misinformation. The International Journal of Press/Politics 2021, 26(1), 277-299

Bulawayo24 News (2020). Available online at https://www.bulawayo24.com Accessed 12/07/20.

Burke, M., Marlow, C. \& Lento, T. (2009). Feed me: Motivating newcomer contribution in social network sites. In Proceedings of the 27th International Conference on Human Factors in Computing Systems (pp. 945-995). New York, NY: ACM.

Chadwick, A. \& Vaccari, C. (2019). News sharing on UK social media: Misinformation, disinformation, and correction.

Chikosi, T. (2020). Zimbabwe: Potraz Demystifies Link between Covid-19 and 5G Network. Available online at https://www.allafrica.net Accessed 12/07/20.

Chou, W.Y.S., Oh, A. \& Klein, W.M. (2018). Addressing Health-Related Misinformation on Social Media. JAMA American Medical Association, 320, 2417-2418.

Davis, S. (2020). Debunked: No, Lemon in Hot Water is not a Cure for Covid-19. Available online at https://www.uronews.com Accessed 12/07/20.

Frenkel, S., Alba, D. \& Zhong, R. (2020). Surge of Virus Misinformation Stumbs Facebook and Twitter. Available online at https://www.nytimes.com Accessed 12/07/20.

France 24 Available online at http://www.twitter.com Accessed 12/07/20.

Hua, J. \& Shaw, R. (2020). Corona Virus (COVID-19) "Infodemic" and Emerging Issues through a Data Lens: The Case of China. International Journal of Environmental Research and Public Health, 17(7), 2309; https://doi.org/10.3390/ijerph17072309

Hill, K. (2012). Hurricane Sandy, @ComfortablySmug, and the Flood of Social Media Misinformation. Available online at http://www.forbes.com/sites/kashmirhill/2012/10/30/hurricane-sandy-andthe-flood-of-socialmedia-misinformation. Accessed 12/07/20.

Hu, Z., Yang, Z., Li, Q., Zhang, A. \& Huang, Y. (2020). Infodemiological Study on COVID-19 Epidemic and COVID-19 Infodemic. Preprints 2020, 2020020380 doi: 10.20944/preprints202002.0380.v3. 
Hughes, A. L., Palen, L. \& Peterson, S. (2014). Critical issues in disaster science and management: A dialogue between researchers and practitioners. In J. E. Trainor \& T. Subbio (Eds.), Journal of Emergency Nursing, pp. 349-392.

Khan, M.L. \& Idris, I.K., (2019) Recognise misinformation and verify before sharing: a reasoned action and information literacy perspective, Behaviour \& Information Technology, 38(12), 1194-1212. DOI: 10.1080/0144929X.2019.1578828.

Kim, L., Fast, M.N. \& Markuzon, N. (2020). Incorporating media data into a model of infectious disease transmission. PloS one, 14(2).

Komisarenko, S. (2020). Covid-19 is not a Bioweapon made by China. Available online at https://newseu.cgtn.com Accessed 14/07/20.

Kwak, H., Lee, C., Park, H. \& Moon, S. (2010). What is twitter, A Social Network or a News Media? In World Wide Web Conference. ACM Press. Publication: WWW '10: Proceedings of the 19th international conference on World wide web April 2010 Pages 591600https://doi.org/10.1145/1772690.1772751

Mabunda, E. (2020). Zimbabwe and South Sudan, Africa's Most Vulnerable to Covid-19-UN. Available online at https://www.equityxis.net Accessed 12/07/20.

Magzter Largest Digital Magazine (2020). Available online at https://www.magzter.com Accessed on 12/07/20.

Marbot, O. (2020). Coronavirus: Unpacking the Theories Behind Africa's Low Infection Rate. Available online at https://www.theafricareport.com Accessed 13/07/20.

Maromo, J. (2020). 'Hundreds of Zimbabweans Leave south Africa in Assisted Repatriation' Available online at https://www.iol.co.za Accessed12/07/20.

Ministry of Health Zimbabwe. (2020). Covid 19 update Available online at https://www.mohcc.gov.zw Accessed 10/07/20.

Muronzi, C. (2020). We'll Die of Hunger First: despair as Zimbabwe Lock down Begins. Available online at https://www.aljazeera.com Accessed 12/07/20.

New Zimbabwe (2020). Coronavirus Zimbabwe \& DiasporaAvailable online at https://www.newzimbabwe.com Accessed 05/0720.

Pennycook, G. et al. (2020a). Understanding and Reducing the Spread of Misinformation Online. PsyArXiv Working Paper, pp.1-63.

Policy Briefing (2020). Viral Lies: Misinformation and the Coronavirus. Article-19 Available online at www.article19.org.

Schiffrin, D., Tannen, D. \& Hamilton, H.E. (eds) (2003). The handbook of discourse analysis. Oxford: Blackwell.

Searle, J. R. (1969). Speech acts. An essay in the philosophy of language. Cambridge: University Press.

Sharma, M. et al. (2017). Zika virus pandemic-analysis of Facebook as a social media health information platform. American Journal of Infection, 145(3), 301-302.

The Financial Gazette (2020). Netflix shares plunge amid fears coronavirus boom is overAvailable online at https://www.financialgazzette.co.zw Accessed 10/07/20.

The Guardian (2020). Coronavirus. Available online at https://www.theguardian.com Accessed 12/07/20. 
Pharos Journal of Theology ISSN 2414-3324 online Volume 102 - Special Ed 2 (2021)

Copyright: @2021 Open Access/Author/s - Online @ http//: www.pharosjot.com

The Herald (2020). Zimbabwe: 25,000 Arrested for Disregarding Lockdown. https://www.allafrica.com Accessed 14/07/2020.

The Indian Express (2020). Countries are Returning Masks Imported from China: Here's why. Available online at https://indianexpress.com Accessed on 12/07/20.

The Standard (2020). Makandiwa, Bill Gates Vaccines and Microchips. Accessed on 12/07/20. Available online at https://www.thestandard.co.zw/2020/04/12/makandiwa-billgates-vaccines-microchips/

WHO. (2020). Available online at https://www.sokodirectory.com Accessed 27/04/20.

WHO. https://www.who.int Accessed 02/07/20. 